\title{
XXX. On a new rain gauge
}

\section{Rev. Thomas Knox M.R.I.A.}

To cite this article: Rev. Thomas Knox M.R.I.A. (1837) XXX. On a new rain gauge , Philosophical Magazine Series 3, 11:67, 260-260, DOI: 10.1080/14786443708649271

To link to this article: http://dx.doi.org/10.1080/14786443708649271

册 Published online: 01 Jun 2009.

Submit your article to this journal $\pi$

LII Article views: 2

Q View related articles $₫$ 
giving the same mean result to four decimal places. Professor Hansteen has given $\cdot 8428$, which must be considered as a close coincidence.*

For Brussels I find by "No. I." ........ 0.960

Captain Sabine

$$
\text { by " Flat," …..... } 0.965
$$

M. Quetelet (4 series) .............. 0.964

M. Rudberg ......................... 0.971

I subjoin a few comparisons of stations common to M. Quetelet's seriest and mine.

\begin{tabular}{|c|c|c|}
\hline & Quetelet. & Forbes, No. 1 \\
\hline 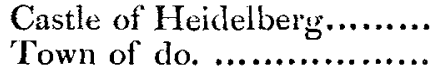 & $\left.\begin{array}{l}1 \cdot 020 \\
1.024\end{array}\right\}$ & 1.017 \\
\hline Königstuhl (summit)......... & 1.027 & $1 \cdot 018$ \\
\hline Geneva $\ldots \ldots \ldots \ldots \ldots \ldots \ldots \ldots$ & $1 \cdot 080$ & $1 \cdot 076$ \\
\hline Chamouni ................. & $1 \cdot 093$ & $1 \cdot 085$ \\
\hline St. Bernard $\quad \ldots . . . . . . . .$. & $1 \cdot 097$ & $1 \cdot 082$ \\
\hline Martigny $\quad \ldots \ldots \ldots \ldots \ldots \ldots$ & $1 \cdot 092$ & 1.083 \\
\hline
\end{tabular}

[To be continued.]

XXX. On a Nero Rain Gauge. By the Rev. Thomas Knox, M. KR.T.A.

[With a Figure: Plate II.]

$\mathbf{O}$

$\mathrm{N}$ the 26th of June last, a new rain-gauge was exhibited to the Royal Irish Academy, contrived by the liev. Thomas Knox.

The object of this instrument is to register the amount of rain that falls when the wind is in different points. Its construction is very simple. The water,-instead of descending from the reservoir directly into the tube of registry, - passes through a lateral tube into an annular-shaped vessel, divided into eight compartments, each of which terminates below in a graduated glass tube. It is obvious, then, that if the eight tubes be set to correspond with the cardinal and intermediate points, and that the reservoir be made to revolve on a vertical axis by means of a vane, the direction of which corresponds with that of the lateral tube, the object proposed will be attained. Mr. Knox has preferred to make the reservoir fixed, and the system of tubes moveable; but the result is obviously the same.

* Since this paper was read, this result has been still more nearly confirmed by the observations of Professor Bache of Philadelphia, who, by conrecting Edinburgh and Dublin, and taking Professor Lloyd and Captain Sabine's observations for the comparative intensities at Dublin and Paris, has obtained the number 8400 .

$\uparrow$ See his two papers in the Mcinoires de l'Academic de Brurclles, tome iv.; and an abstract in the Annuare de l'Observatuire de Brure'les, 1834,

f From the Iroceedings of the Royal Ilish Academy, No. 5 . 


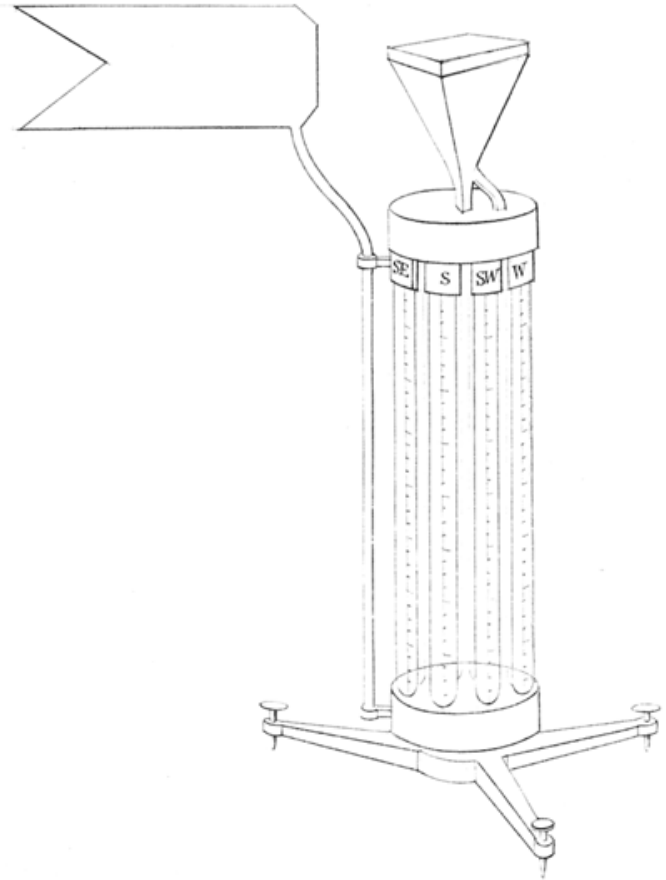

The Rev Mr Knox's Rain Guage

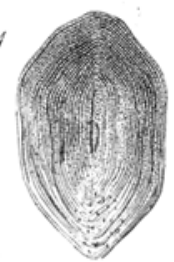

2

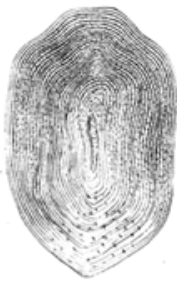

5

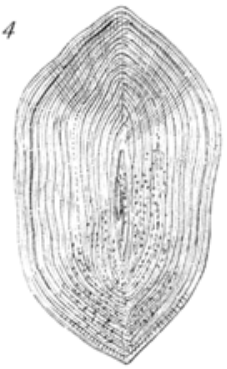

3

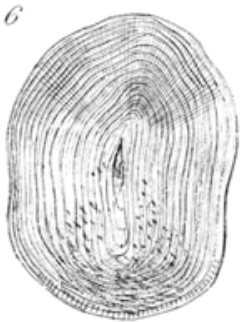

